\title{
A Synthetic Mimic of Protein Inner Space: Buried Polar Interactions in a Deep Water-Soluble Host
}

Sara M. Butterfield and Julius Rebek, Jr.*

The Skaggs Institute for Chemical Biology and the Department of Chemistry, The Scripps

Research Institute, 10550 North Torrey Pines Road, La Jolla, California 92037

\section{General Experimental}

All reagents were obtained from the commercial suppliers and used without further purification. ${ }^{1} \mathrm{H}$ NMR spectra were obtained using a Bruker DRX-600 spectrometer. Infrared absorption spectra were obtained using a Perkin-Elmer Paragon FT-IR spectrometer.

\section{Synthetic Procedures}

\section{A. Hexanitro Cavitand 10.}

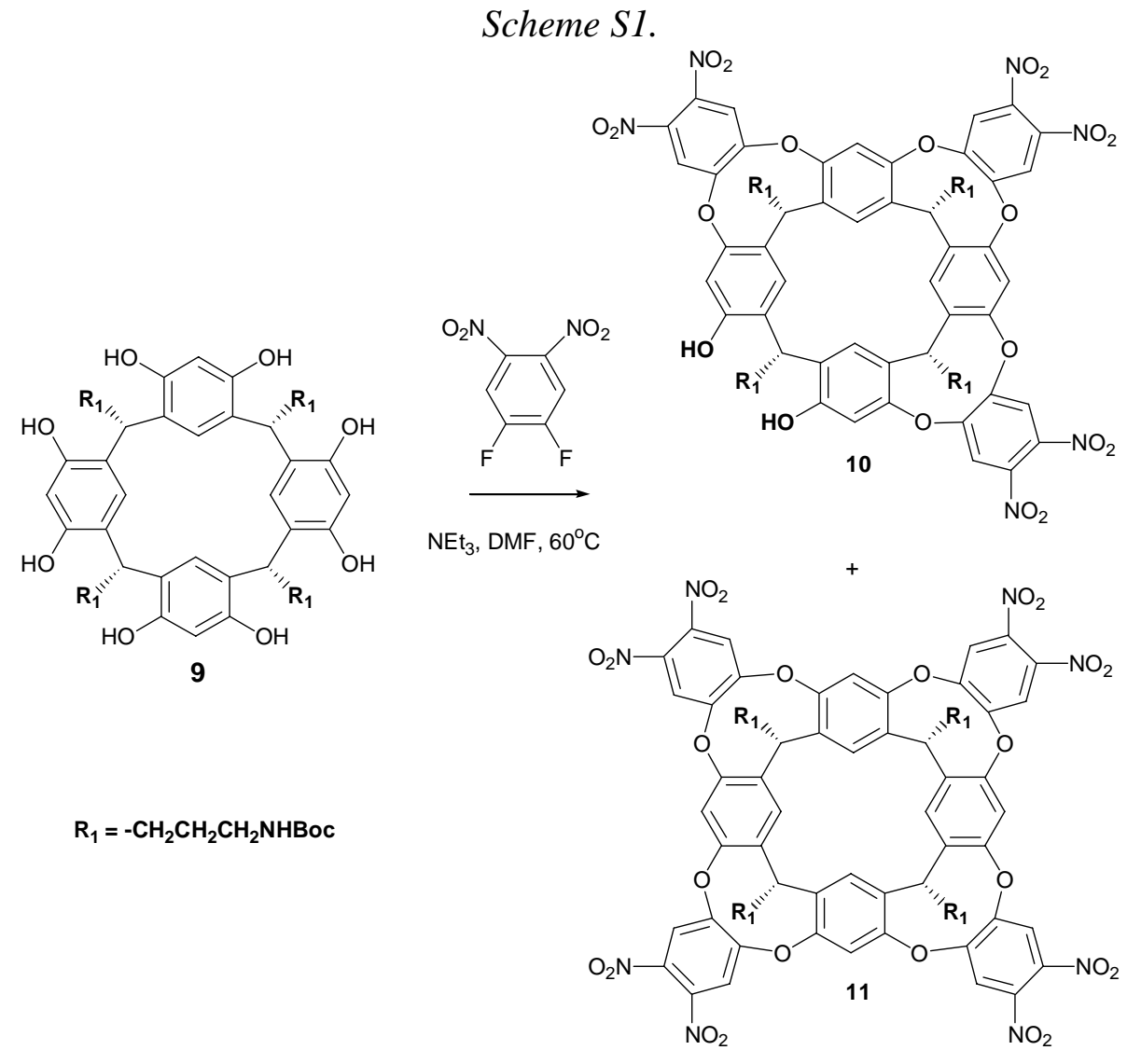


Known NHBoc-footed resorcinarene 9 was prepared as previously described. ${ }^{1} 9$ (2 g, $1.79 \mathrm{mmol})$ and 1,2-difluoro-4,5-dinitrobenzene $(904 \mathrm{mg}, 4.48 \mathrm{mmol})$ were dissolved in $100 \mathrm{ml}$ dry DMF under argon at $0^{\circ} \mathrm{C}$. Triethylamine $(2.5 \mathrm{ml}, 17.9 \mathrm{mmol})$ was added dropwise and the reaction was then stirred at $60^{\circ} \mathrm{C}$ overnight. Removal of the solvent by rotary evaporation followed by flash chromatography $(8 \%$ ethylacetate in dichloromethane) using a chromatotron allowed the isolation of hexanitro-cavitand 10 (380 mg, 13\%) after several purifications. ${ }^{1} \mathrm{H}$ NMR ( $\mathrm{d}_{6}$-acetone, $\left.600 \mathrm{MHz}\right) \delta 8.6$ (br s, $\mathrm{ArOH}), 8.13(\mathrm{~m}, 4 \mathrm{H}), 8.02(\mathrm{~s}, 2 \mathrm{H}), 7.96(\mathrm{~s}, 1 \mathrm{H}), 7.38-7.22(\mathrm{~m}, 4 \mathrm{H}), 7.13(\mathrm{~s}, 1 \mathrm{H}), 6.76$ (s, $2 \mathrm{H}), 6.05$ (m, $4 \mathrm{H}, \mathrm{NHBoc}), 4.55-4.45$ (m, 3H, ArCHRAr), 4.36 (s, 1H, ArCHRAr) 3.15-3.05 (m, $8 \mathrm{H}, \mathrm{CH}_{2} \mathrm{NHBoc}$ ), 2.3-2.12 (m, $8 \mathrm{H}, \mathrm{CH}_{2} \mathrm{CH}_{2} \mathrm{CH}_{2} \mathrm{NHBoc}$ ), 1.42-1.26 (m, $44 \mathrm{H}, \mathrm{CH}_{2} \mathrm{CH}_{2} \mathrm{NHBoc}$ and $\mathrm{NHBoc} \mathrm{CH}_{3}$ ). MS (ESI-TOF high accuracy) calcd. for $\mathrm{C}_{78} \mathrm{H}_{84} \mathrm{~N}_{10} \mathrm{O}_{28}$ 1608.545, found [M $\left.+\mathrm{Na}^{+}\right]$1631.530. IR $\left(\mathrm{cm}^{-1}\right) 3434$ (br), 3351 (br), 2972, 2928, 2868, 1701, 1685, 1588, 1542, 1363, 1281, 1251, 1191, 1166.

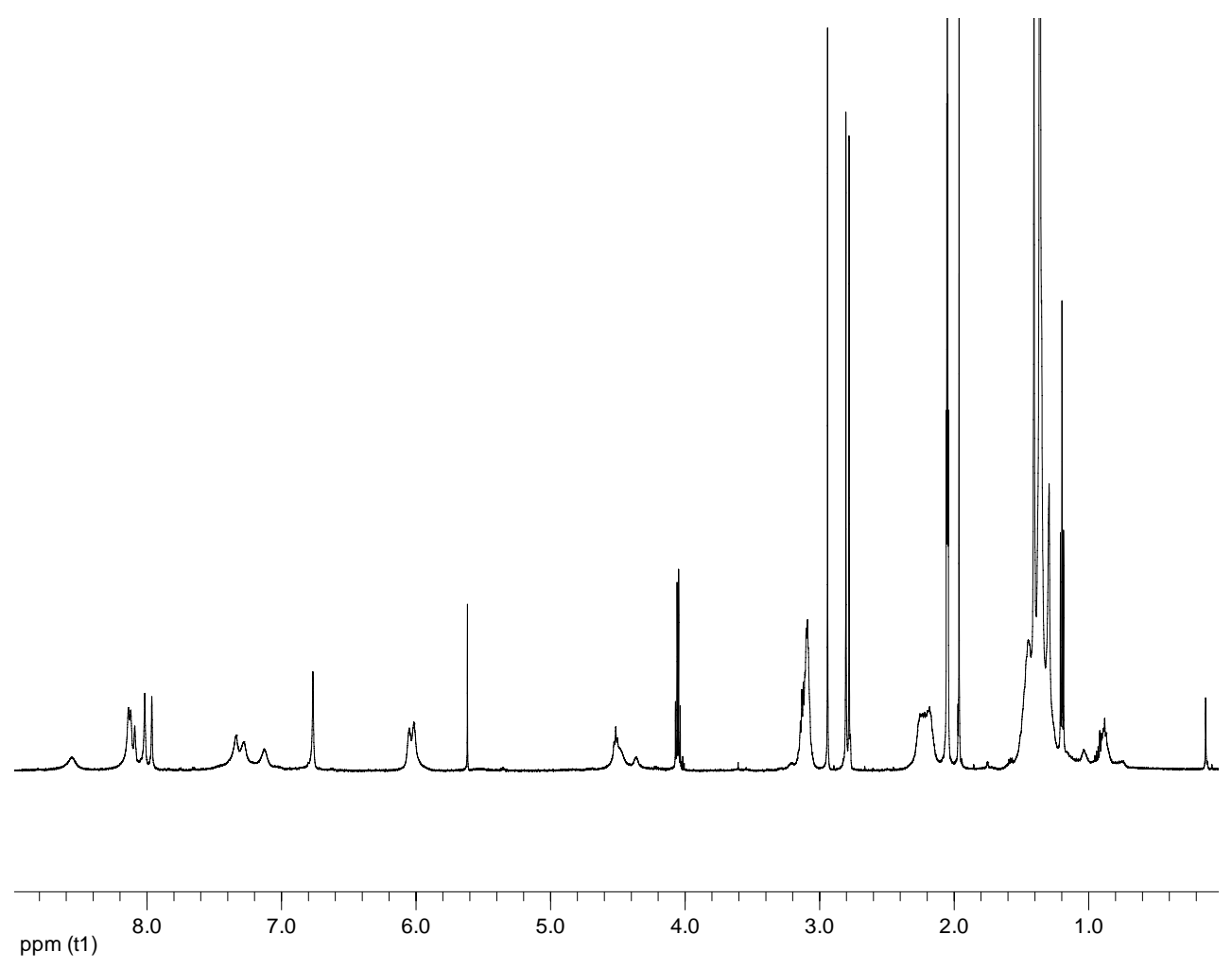

Figure S1. Cavitand 10 


\section{B. Hexamide Diol 12 and Hexamide Dinitro 13.}

Scheme S2.

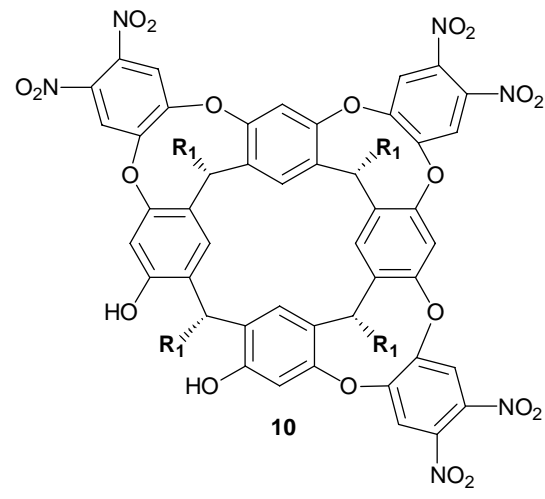

$\mathrm{R}_{1}=-\mathrm{CH}_{2} \mathrm{CH}_{2} \mathrm{CH}_{2} \mathrm{NHBoc}$

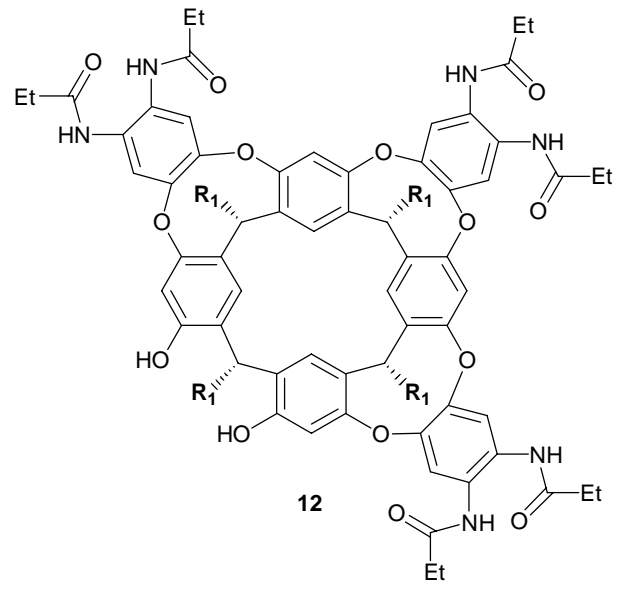

$\mathrm{R}_{1}=-\mathrm{CH}_{2} \mathrm{CH}_{2} \mathrm{CH}_{2} \mathrm{NHBoc}$
1. Raney $\mathrm{Ni}, \mathrm{H}_{2}$ THF, $40^{\circ} \mathrm{C}$

2. $\mathrm{CH}_{3} \mathrm{CH}_{2} \mathrm{COCl}, \mathrm{K}_{2} \mathrm{CO}_{3}$ $\mathrm{EtOH}-\mathrm{H}_{2} \mathrm{O}$

3. hydrazine, toluene-EtOH
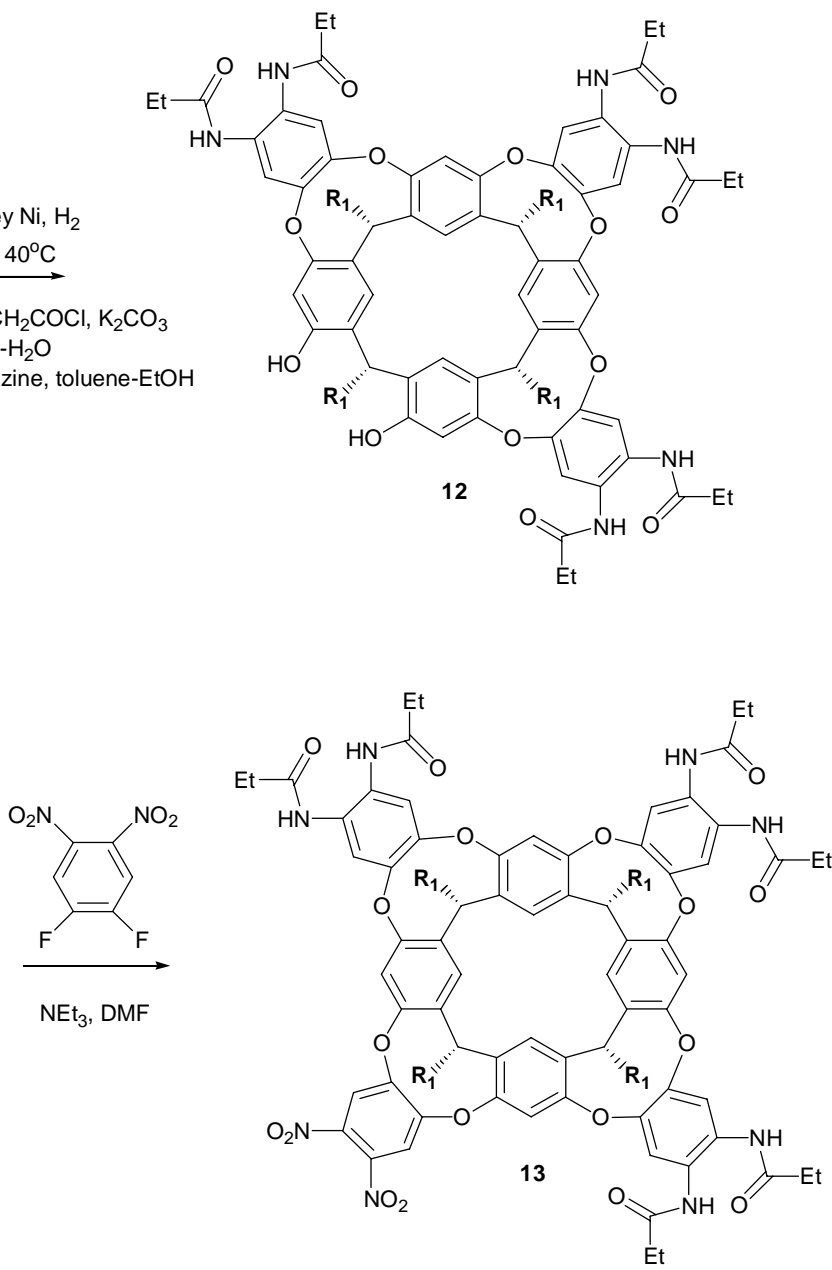

Hexanitro cavitand $10(470 \mathrm{mg}, 0.29 \mathrm{mmol})$ was dissolved in $120 \mathrm{ml}$ dry THF. A catalytic amount of Raney nickel in THF was added and the reaction mixture was placed under an $\mathrm{H}_{2}$ atmosphere and stirred overnight at $40^{\circ} \mathrm{C}$. The reaction mixture was filtered through a pad of celite, rinsed with methanol and dried in vacuo overnight to generate the crude hexamine cavitand. The hexamine cavitand was taken up in $30 \mathrm{ml}$ of ethyl acetate in a beaker. 30 equivalents of $\mathrm{K}_{2} \mathrm{CO}_{3}(8.8 \mathrm{mmol}, 1.21 \mathrm{~g})$ dissolved in $22 \mathrm{ml}$ of water was added slowly to the beaker followed by $30 \mathrm{ml}$ of EtOAc and the solution was stirred vigorously. Propionyl chloride was added $(2 \mathrm{X} 380 \mu \mathrm{l})$ to the stirring reaction mixture, waiting 30 minutes in between each addition. The organic layer was separated and combined with two extractions of the water layer. The organic layer was washed with brine, dried over $\mathrm{Na}_{2} \mathrm{SO}_{4}$, and rotovapped to dryness. The crude hexamide diester was dissolved in $50 \mathrm{ml} \mathrm{1:1}$ toluene:EtOH under argon. Anhydrous hydrazine (125 $\mu \mathrm{l})$ was added via syringe and the reaction was stirred at $80^{\circ} \mathrm{C}$ for $1 \mathrm{hr}$. The reaction was then rotovapped and purified by column chromatography (2:3 EtOAc:DCM, then 5\% MeOH 
in DCM) to obtain the pure hexamide diol cavitand $12(152 \mathrm{mg}, 30 \%) .{ }^{1} \mathrm{H}$ NMR $\left(\mathrm{d}_{6^{-}}\right.$ acetone, $600 \mathrm{MHz}) \delta 9.53(\mathrm{~s}, 1 \mathrm{H}) 9.41(\mathrm{~s}, 1 \mathrm{H}) 9.06(\mathrm{~s}, 1 \mathrm{H}) 8.92(\mathrm{~s}, 2 \mathrm{H}) 7.88(\mathrm{~s}, 2 \mathrm{H})$ $7.76(\mathrm{~s}, 2 \mathrm{H}) 7.72-7.66(\mathrm{~m}, 4 \mathrm{H}) 7.53(\mathrm{~s}, 2 \mathrm{H}) 6.75(\mathrm{~s}, 2 \mathrm{H}) 6.09(\mathrm{br} \mathrm{s}, 4 \mathrm{H}) 5.85(\mathrm{~s}, 1 \mathrm{H}) 5.72$ (br s, 2H), $4.38(\mathrm{t}, 1 \mathrm{H} \mathrm{J}(\mathrm{H}, \mathrm{H})=7.8 \mathrm{~Hz}), 3.19(\mathrm{~m}, 8 \mathrm{H}) 2.6-2.25(\mathrm{~m}, 20 \mathrm{H})$ 1.64-1.5 (m, $8 \mathrm{H}) 1.42(\mathrm{~s}, 36 \mathrm{H}) 1.30-1.16(\mathrm{~m}, 14 \mathrm{H}), 1.14-1.07(\mathrm{~m}, 4 \mathrm{H}) . \quad$ MS (ESI-MS in acetone) calcd. for $\mathrm{C}_{96} \mathrm{H}_{120} \mathrm{~N}_{10} \mathrm{O}_{22}$ 1764.858, found $\left[\mathrm{M}+\mathrm{Na}^{+}\right]$1787.859. IR $\left(\mathrm{cm}^{-1}\right) 3335$ (br), 2973, 29344, 1701, 1685, 1673, 1654, 1506, 1498, 1489, 1251, 1166.

$12(110 \mathrm{mg}, 0.062 \mathrm{mmol})$ and 1,2-difluoro-4,5-dinitrobenzene $(26 \mathrm{mg}, 0.128 \mathrm{mmol})$ were dissolved in $10 \mathrm{ml}$ DMF under argon at $0^{\circ} \mathrm{C}$ with stirring. Triethylamine $(86 \mu 1,0.62$ mmol) was added via syringe and the reaction was stirred for 4 hours at $40^{\circ} \mathrm{C}$. The reaction was then rotovapped and purified by column chromatography (2:3 ethylacetate:dichloromethane) to obtain pure hexamide dinitro cavitand 13 (76 mg, 63\%). ${ }^{1} \mathrm{H}$ NMR (d ${ }_{6}$-acetone) $\delta$ 9.6-9.3 (m, 4H) 8.6-8.4 (m, 4H) $8.07(\mathrm{~s}, 2 \mathrm{H}) 7.95-7.85(\mathrm{~m}, 4 \mathrm{H})$ 7.8-7.71 (m, 4H) $7.69(\mathrm{~s}, 2 \mathrm{H}) 7.55(\mathrm{~s}, 2 \mathrm{H}) 6.10(\mathrm{br} \mathrm{s}, 4 \mathrm{H}) 5.86(\mathrm{~m}, 3 \mathrm{H}) 5.68(\mathrm{br} \mathrm{s}, 1 \mathrm{H})$ 3.25-3.15 (m, 8H) 2.55-2.32 (m, 20H) 1.65-1.5 (m, $8 \mathrm{H}) 1.42(\mathrm{~m}, 36 \mathrm{H}) 1.25-1.13(\mathrm{~m}$, $18 \mathrm{H}$ ). MS (ESI-TOF high accuracy in acetone) cald. for $\mathrm{C}_{102} \mathrm{H}_{122} \mathrm{~N}_{12} \mathrm{O}_{26} 1930.86$, cald. for $\left[\mathrm{M}+\mathrm{Na}^{+}\right]=1953.8485$, found $\left[\mathrm{M}+\mathrm{Na}^{+}\right]$1953.8422. IR $\left(\mathrm{cm}^{-1}\right) 3390(\mathrm{br}), 2973,2934$, $1685,1671,1506,1482,1402,1364,1273,1169$. 


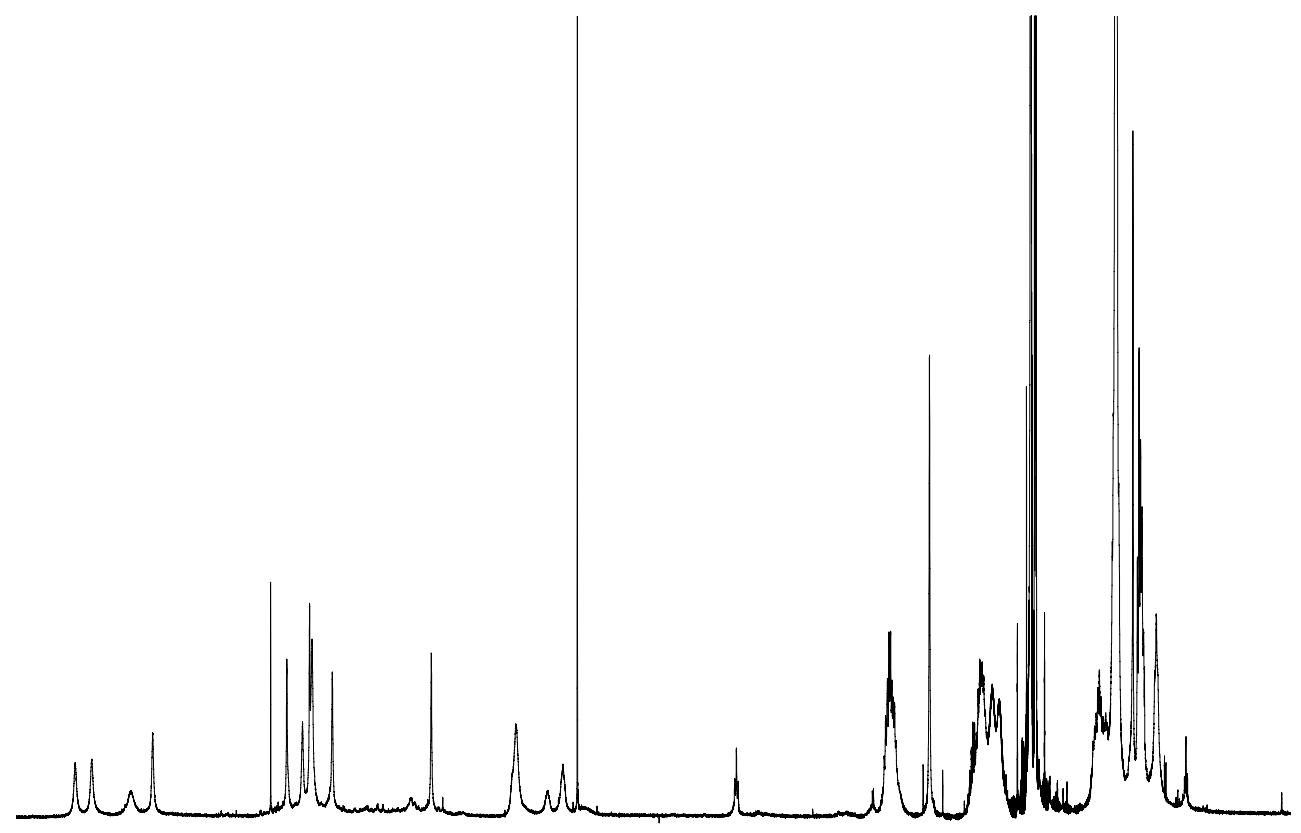

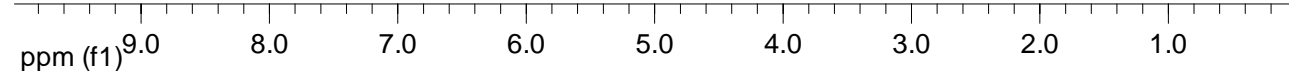

Figure S2. Cavitand 12

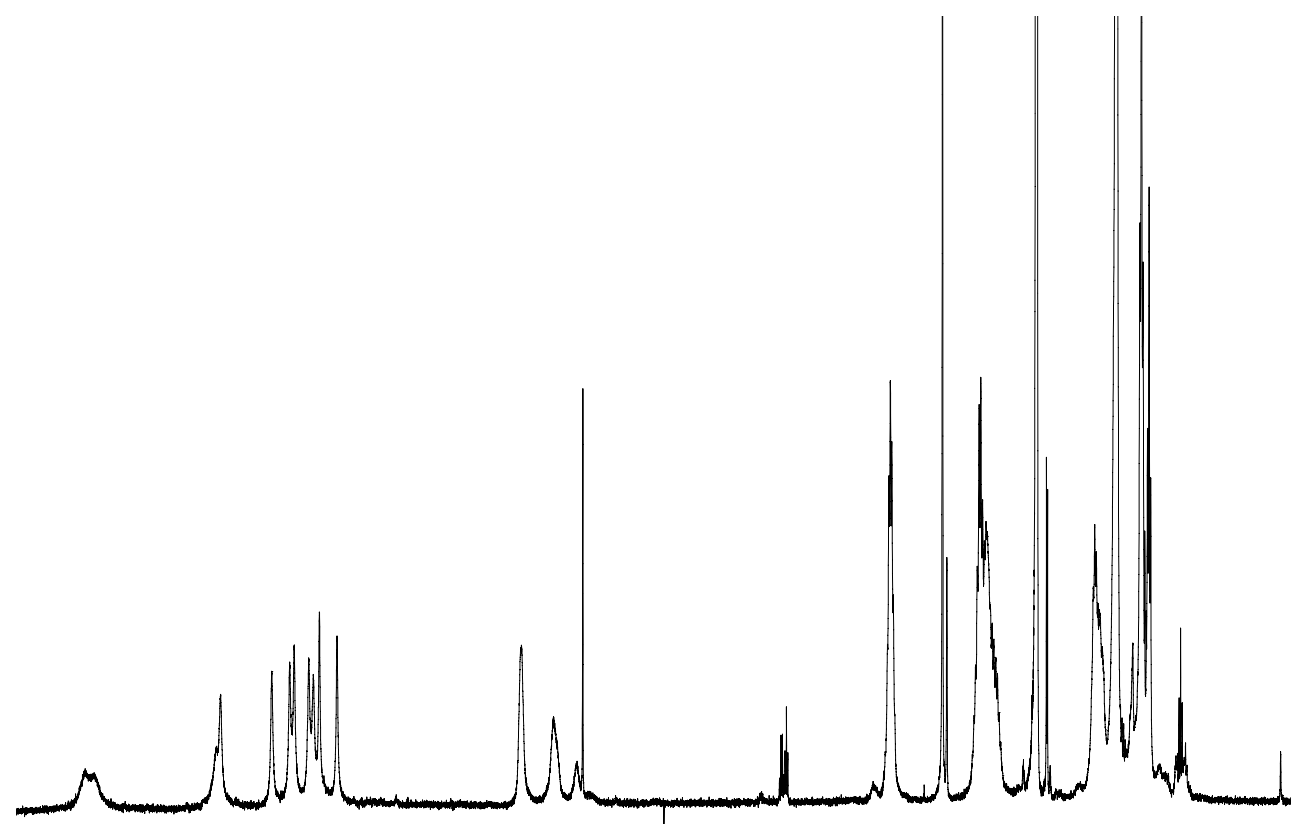

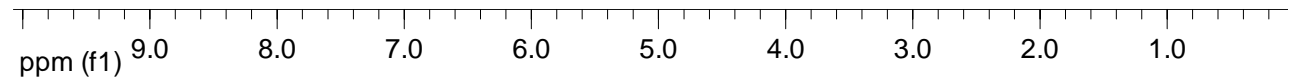

Figure S3. Cavitand 13 


\section{Introverted Acid Cavitands 1 \& 2.}

Scheme S3.
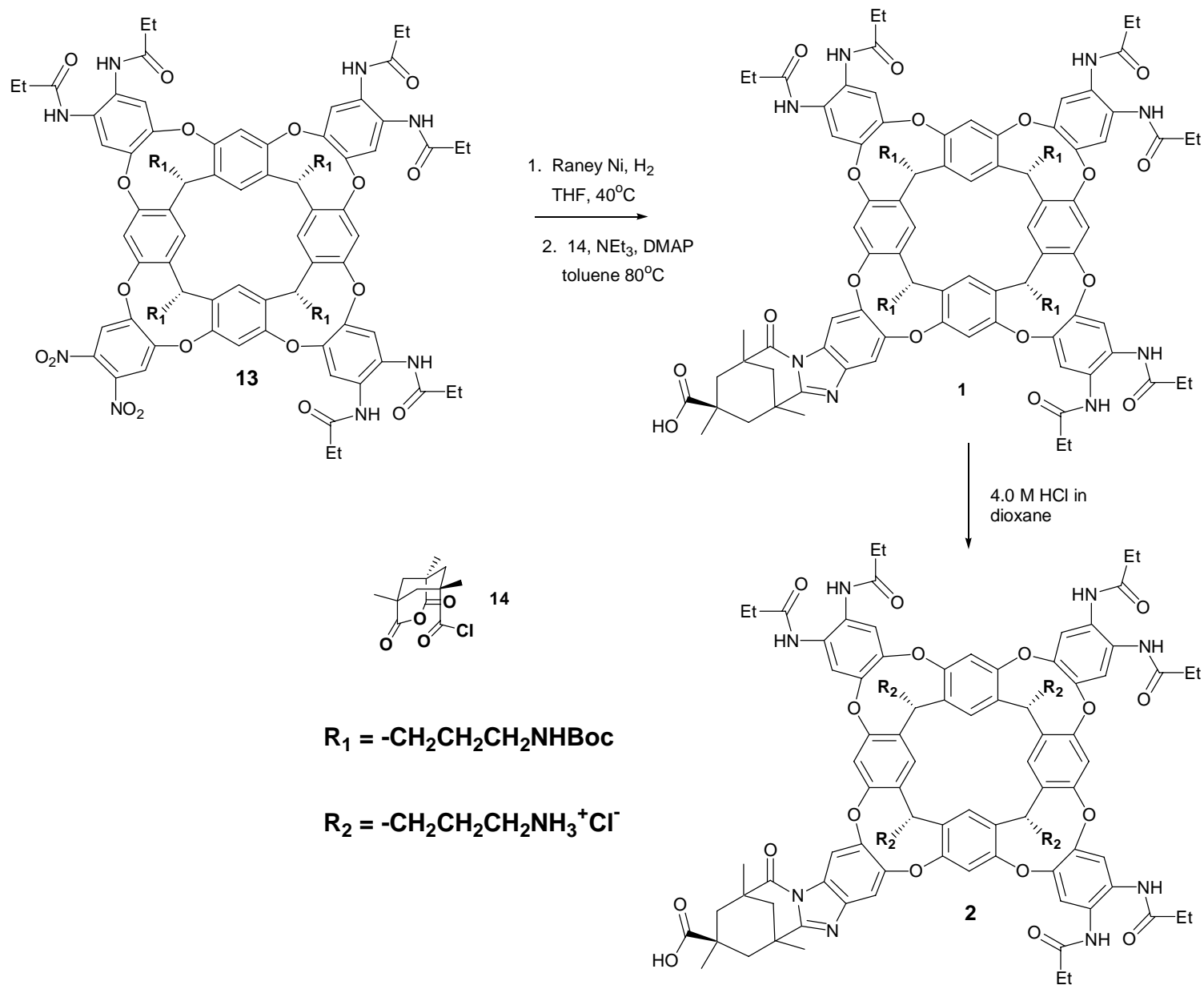

Hexamide dinitro cavitand 13 (76 $\mathrm{mg}, 0.039 \mathrm{mmol})$ was dissolved in $25 \mathrm{ml}$ dry THF. A catalytic amount of Raney nickel in THF was added and the reaction was stirred under $\mathrm{H}_{2}$ at $40^{\circ} \mathrm{C}$ for 6 hours and was complete by TLC. The reaction was cooled to room temperature, filtered through a pad of celite and dried in vacuo overnight to generate the hexamide diamine cavitand. The hexamide diamine was taken up in $2 \mathrm{ml}$ dry toluene and transferred via syringe to an argon-purged sealed tube loaded with Kemp's triacid chloride anhydride $14(15 \mathrm{mg}, 0.059 \mathrm{mmol})$ and a stir bar. Triethylamine (33 $\mu 1,0.23$ mmol) was transferred to the sealed tube via syringe and the reaction was stirred for 30 min at room temperature, for $6 \mathrm{hrs}$ at $100^{\circ} \mathrm{C}$, and then at room temperature overnight. The reaction mixture was filtered through a pad of celite and extracted with water and brine, and dried over sodium sulfate. The organic layer was rotovapped and the crude cavitand was purified several times by preparative TLC ( $80 \%$ ethyl acetate in DCM) to generate 1 (22 mg, $27 \%$ from 6). ${ }^{1} \mathrm{H} \mathrm{NMR} \mathrm{CDCl}_{3} \delta 9.95(\mathrm{~s}, 1 \mathrm{H}) 9.46(\mathrm{~s}, 1 \mathrm{H}) 9.06(\mathrm{~s}, 1 \mathrm{H})$ $8.56(\mathrm{~s}, 1 \mathrm{H}) 8.22(\mathrm{~s}, 1 \mathrm{H}) 8.03(\mathrm{~s}, 1 \mathrm{H}) 7.93(\mathrm{~s}, 1 \mathrm{H}) 7.80(\mathrm{~s}, 1 \mathrm{H}) 7.73(\mathrm{~s}, 1 \mathrm{H}) 7.65(\mathrm{~s}, 1 \mathrm{H})$ $7.45(\mathrm{~s}, 1 \mathrm{H}) 7.28(\mathrm{~s}, 1 \mathrm{H}) 7.25-7.19(\mathrm{~m}, 8 \mathrm{H}) 7.05(\mathrm{~s}, 1 \mathrm{H}) 5.86(\mathrm{t}, 1 \mathrm{H}) 5.8(\mathrm{t}, 1 \mathrm{H}) 5.74(\mathrm{t}$, 1H) $5.65(\mathrm{t}, 1 \mathrm{H}) 3.35-3.15(\mathrm{~m}, 8 \mathrm{H}) 2.6-2.12(\mathrm{~m}, 20 \mathrm{H}) 1.7-1.58(\mathrm{~m}, 12 \mathrm{H}) 1.48(\mathrm{~s}, 36 \mathrm{H})$ 1.3-1.15 (m, 30H) 0.94-0.8 (m, 12H). MS (ESI-TOF high accuracy in dichloromethane) 
cald. for $\mathrm{C}_{114} \mathrm{H}_{136} \mathrm{~N}_{12} \mathrm{O}_{25}$ 2072.9812, found $\left[\mathrm{M}+\mathrm{H}^{+}\right]$2073.9762. Cavitand 1 (11 mg, $0.0053 \mathrm{mmol}$ ) was then stirred in $200 \mu \mathrm{l} 4.0 \mathrm{M} \mathrm{HCl}$ in dioxane for $45 \mathrm{~min}$ to remove the Boc proctecting groups. The solution was rotovapped, precipitated with acetone and rotovapped several times to generate water-soluble cavitand 2 (8 $\mathrm{mg}, 85 \%)$. Samples of cavitand 2 were dialyzed against water for several hours prior to NMR measurements to remove excess salts. Due to the ill-defined NMR spectra of 2 in the absence of guest, the resonances for the cavitand are reported only when bound to guest 6. ${ }^{1} \mathrm{H}$ NMR $\left(\mathrm{D}_{2} \mathrm{O}\right)$ (sample generated in the presence of excess quinculidine guest, approximately $70 \%$ bound) $\delta 8.05(\mathrm{~s}, 1 \mathrm{H}) 8.02(\mathrm{~s}, 1 \mathrm{H}) 7.98(\mathrm{~s}, 1 \mathrm{H}) 7.93(\mathrm{~s}, 1 \mathrm{H}) 7.89$ (s, 1H) $7.72(\mathrm{~s}, 1 \mathrm{H}) 7.7$ $(\mathrm{s}, 1 \mathrm{H}) 7.68(\mathrm{~s}, 1 \mathrm{H})$ 7.6-7.55 (m, 2H) $7.45(\mathrm{~s}, 1 \mathrm{H})$ 5.85-5.78 (m, 3H, ArCHRAr) $5.7(\mathrm{~m}$, 1H, ArCHRAr) 3.28-3.15 (m, 8H, $\left.\mathrm{CH}_{2} \mathrm{NH}_{3}{ }^{+}\right) 3.1-2.25(\mathrm{~m}, 30 \mathrm{H})$ 1.9-0.8 (m, 60H). MS (MALDI-TOF) cald. for $\mathrm{C}_{94} \mathrm{H}_{104} \mathrm{~N}_{12} \mathrm{O}_{7} 1672.8$, found $\left[\mathrm{M}+\mathrm{H}^{+}\right] 1673.8$.

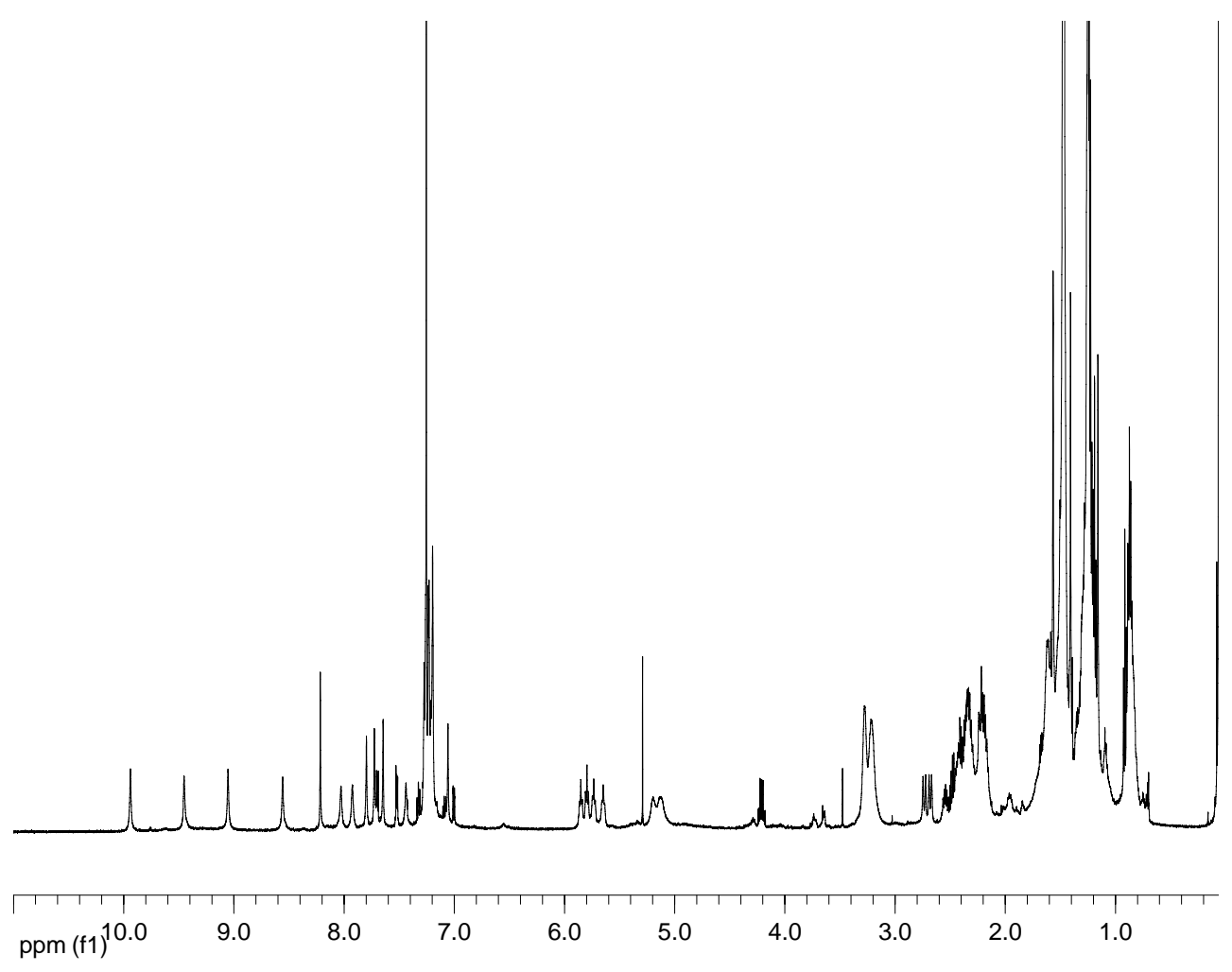

Figure S4. Cavitand 1 


\section{NMR Data}

A. Encapsulation Peaks for Complex ( \pm -1.5 in $\mathrm{CDCl}_{3}$ and water saturated $\mathrm{CDCl}_{3}$.

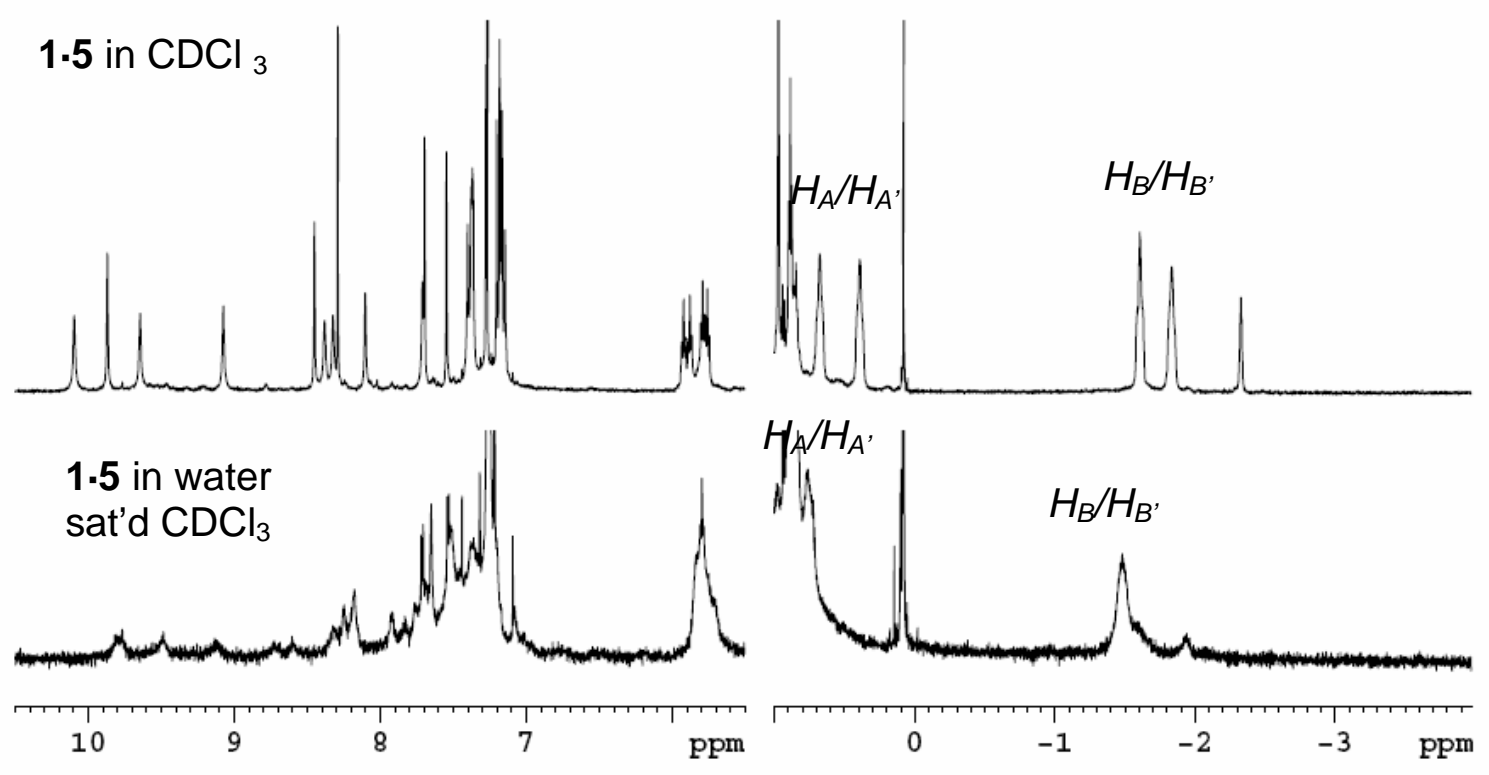

Figure S5. 


\section{B. Exchange Spectrscopy (EXSY) Data.}

\section{Procedure for EXSY Experiments.}

The EXSY spectra of complexes 1·5, 2.6, and $\mathbf{4 \cdot 6}$ were taken at $300 \mathrm{~K}$ at $600 \mathrm{MHz}$ with a phase sensitive NOESY pulse sequence supplied with the Bruker software. For each complex, two spectra were taken, one with $400 \mathrm{~ms}$ mixing time and one with $0 \mathrm{~ms}$ mixing time. MestreC software (Mestrelab Research, Santiago de Compostela) was used to analyze the spectra. Before Fourier Transformation, the FIDs were multiplied by a 90 sine square function in both the $\mathrm{F} 2$ and the $\mathrm{F} 1$ domain. $1 \mathrm{~K} \_1 \mathrm{~K}$ real data points were used, with a resolution of $1 \mathrm{~Hz} /$ point. The rate constant $\mathrm{k}_{\text {in }}$ and $\mathrm{k}_{\text {out }}$ were calculated using the EXSYCALC program (Mestrelab, Santiago de Compostela) ${ }^{2}$, and were used to calculate the chemical exhange barrier, $\Delta \mathrm{G}^{\neq}$diss, for guest exiting the host using the Eyring equation below.

$$
\Delta \mathrm{G}_{\text {diss }}^{\neq}=-\mathrm{RT} \ln \left(k_{\text {out }} \cdot h / k_{\mathrm{B}} \mathrm{T}\right)
$$

$\mathrm{T}=$ temperature; $k_{\mathrm{B}}=$ Boltzmann constant; $h=$ Planck's constant

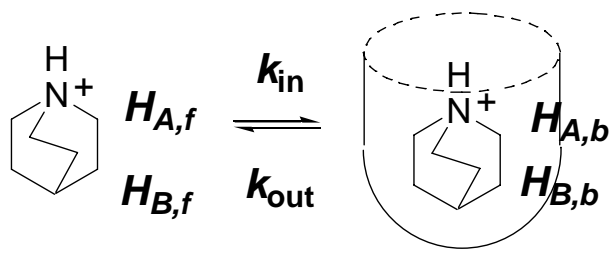

Scheme S4. Exchange process investigated by 2D EXSY.

Table S1. Dissociation Rate Constants

\begin{tabular}{|c|c|}
\hline Complex & $k_{\text {out }} s^{-1}$ \\
\hline $\mathbf{1 \cdot 5}$ & 0.14 \\
\hline $\mathbf{2 \cdot 6}$ & 0.20 \\
\hline $\mathbf{4 \cdot 6}$ & 2.0 \\
\hline
\end{tabular}


2. NOESY Data for $1 \cdot 5$ Complex in $\mathrm{CDCl}_{3}$

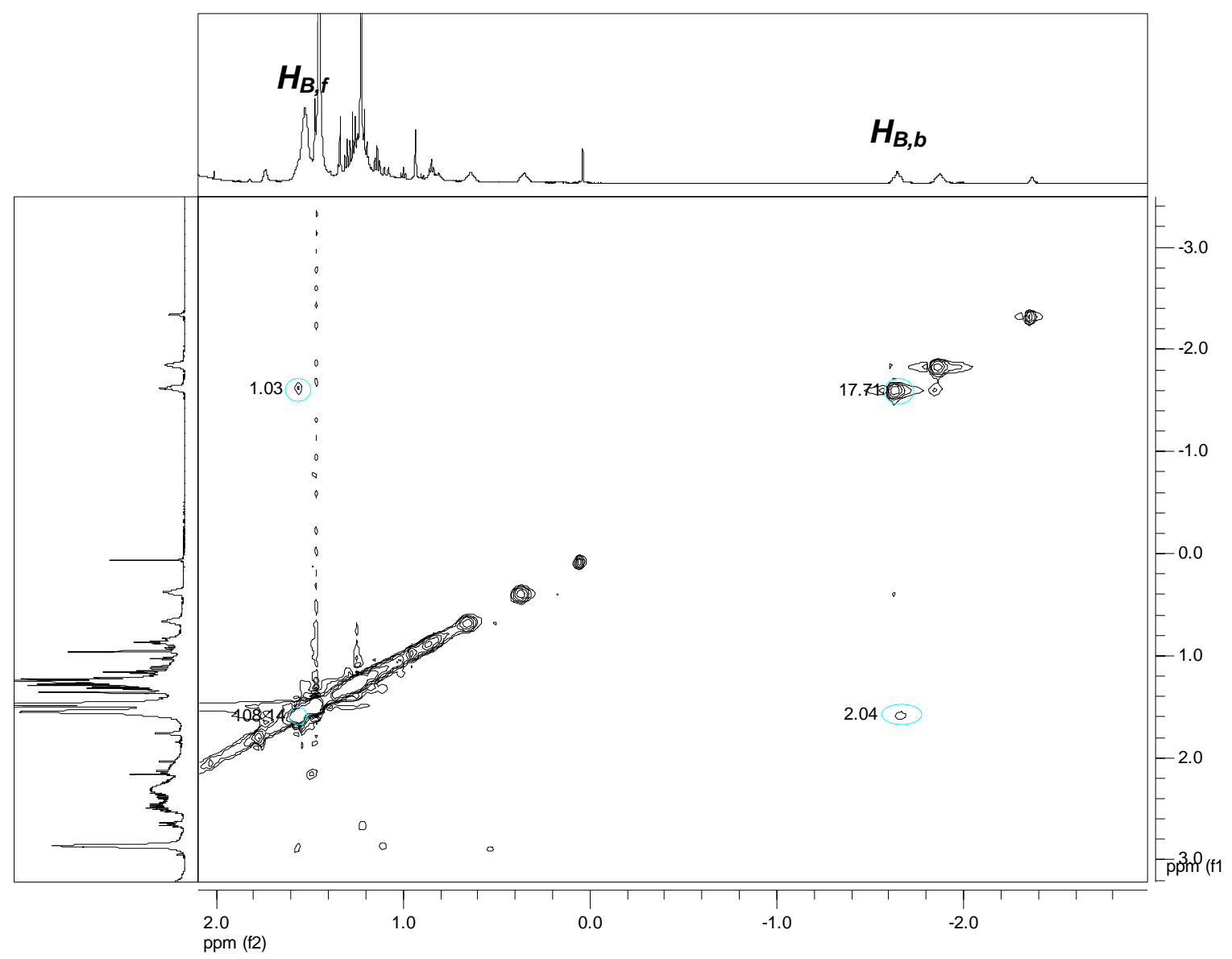

Figure S6. NOESY data for $\mathbf{1 . 5}$ in $\mathrm{CDCl}_{3}$ taken at $400 \mathrm{~ms}$ mixing time. The integrated cross-peaks corresponding to the exchange of bound and free guest protons are shown. 


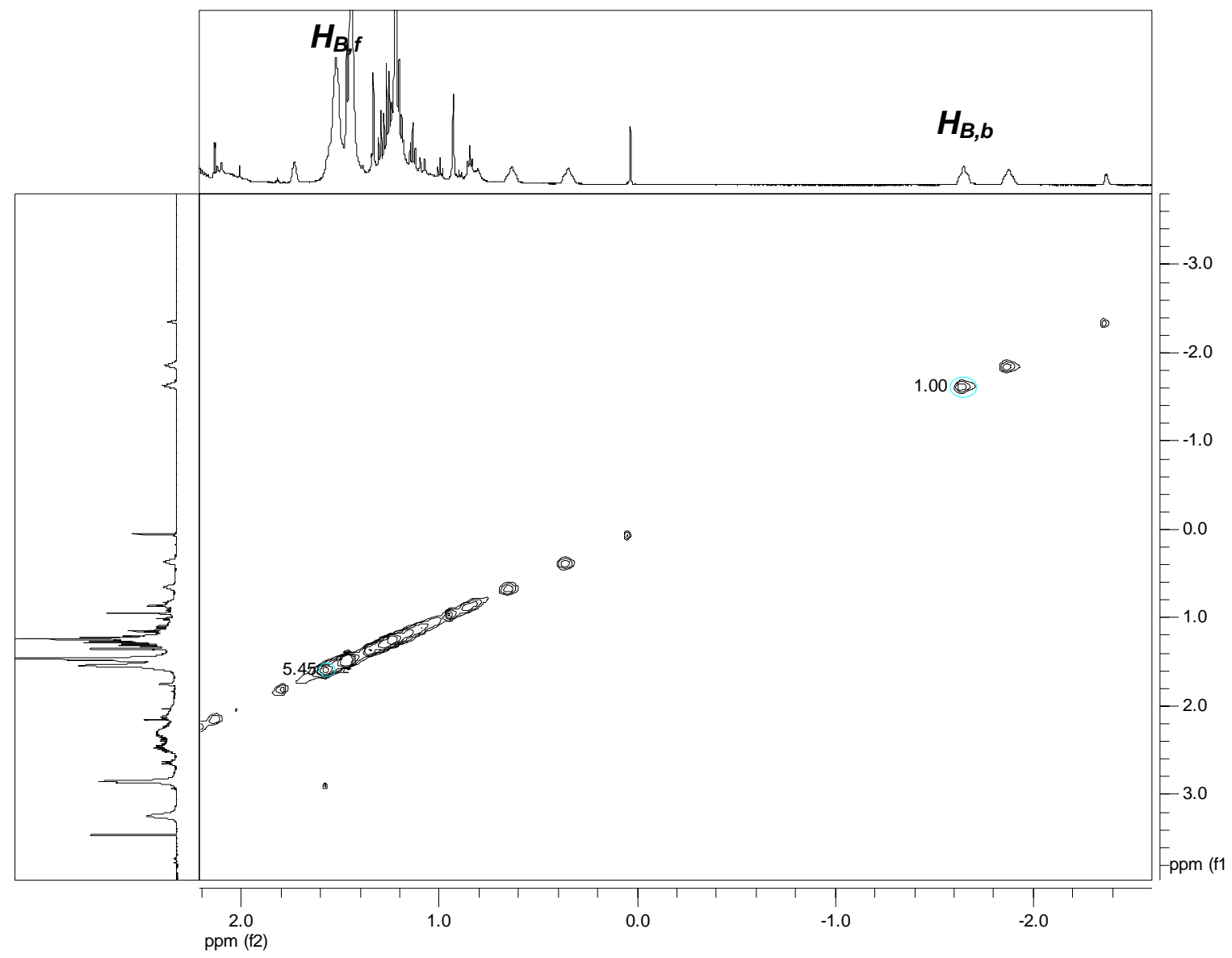

Figure S7. NOESY data of $\mathbf{1 . 5}$ complex at $0 \mathrm{~ms}$ mixing time. 
3. NOESY Data for $\mathbf{2 \cdot 6}$ Complex in $\mathrm{D}_{2} \mathrm{O}$

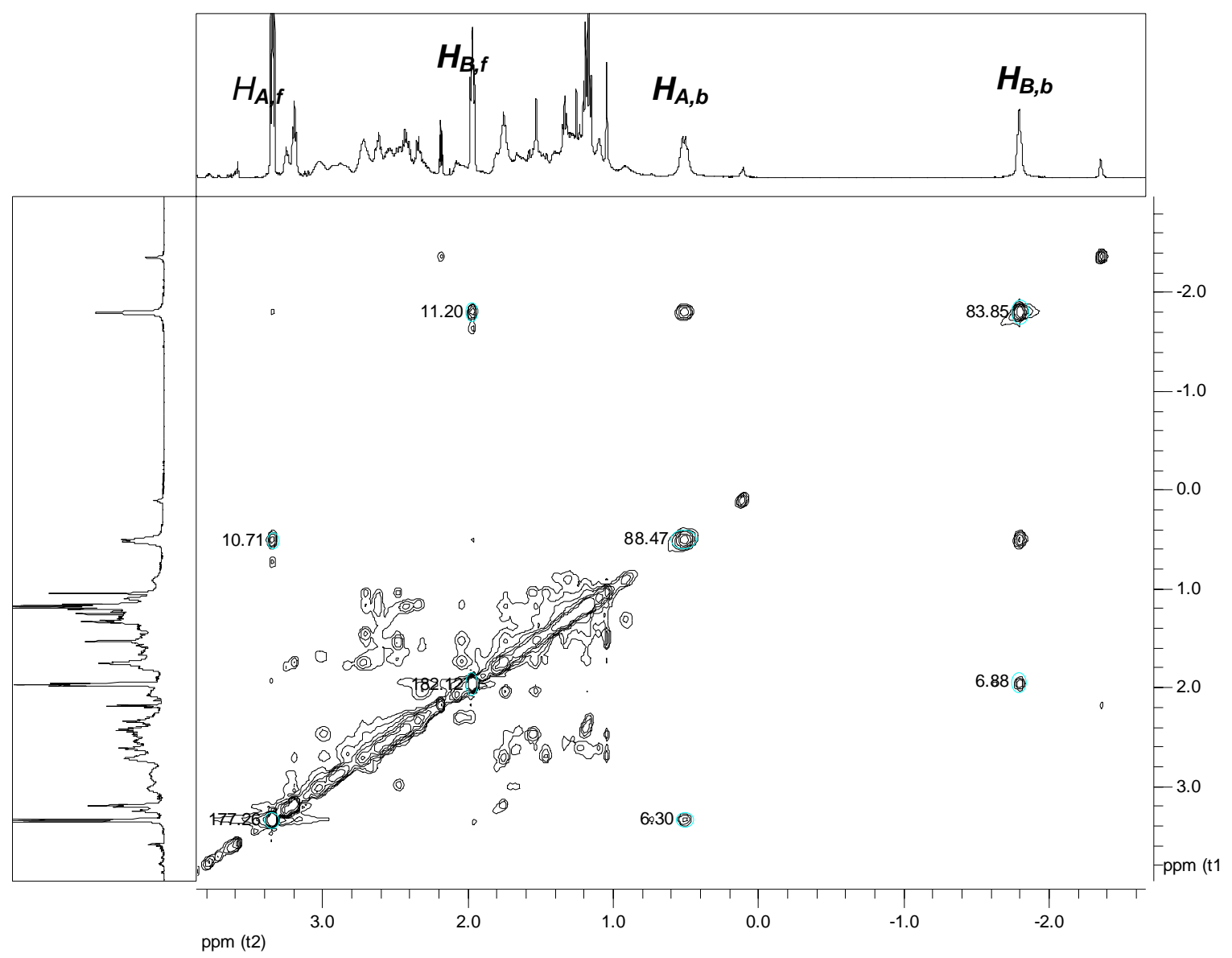

Figure S8. NOESY of $\mathbf{2 \cdot 6}$ in $\mathrm{D}_{2} \mathrm{O}$ taken at $400 \mathrm{~ms}$ mixing time. 


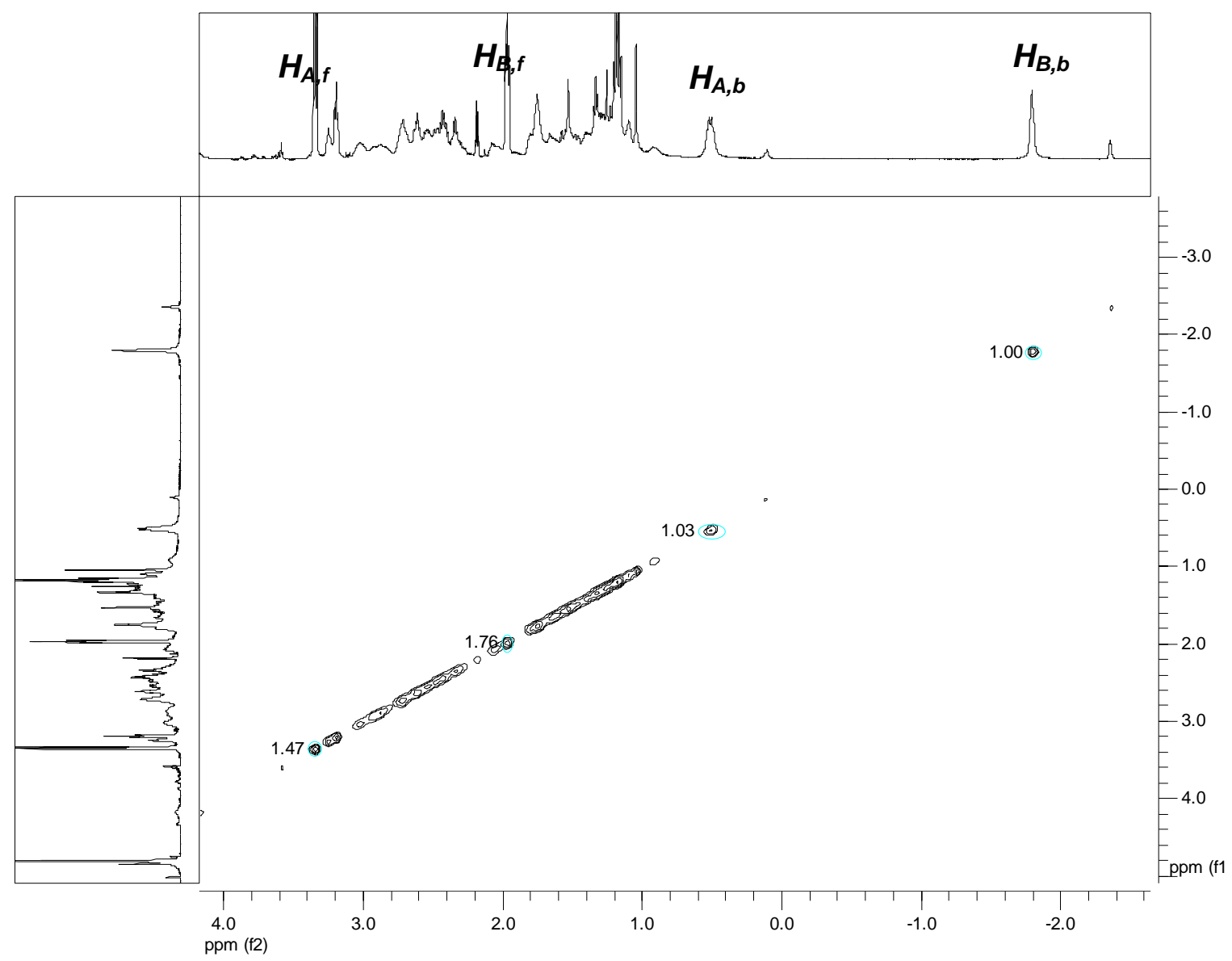

Figure S9. NOESY data for the $\mathbf{2 \cdot} \mathbf{6}$ complex taken at $0 \mathrm{~ms}$ mixing time. 
4. NOESY Data for $\mathbf{4 \cdot 6}$ Complex

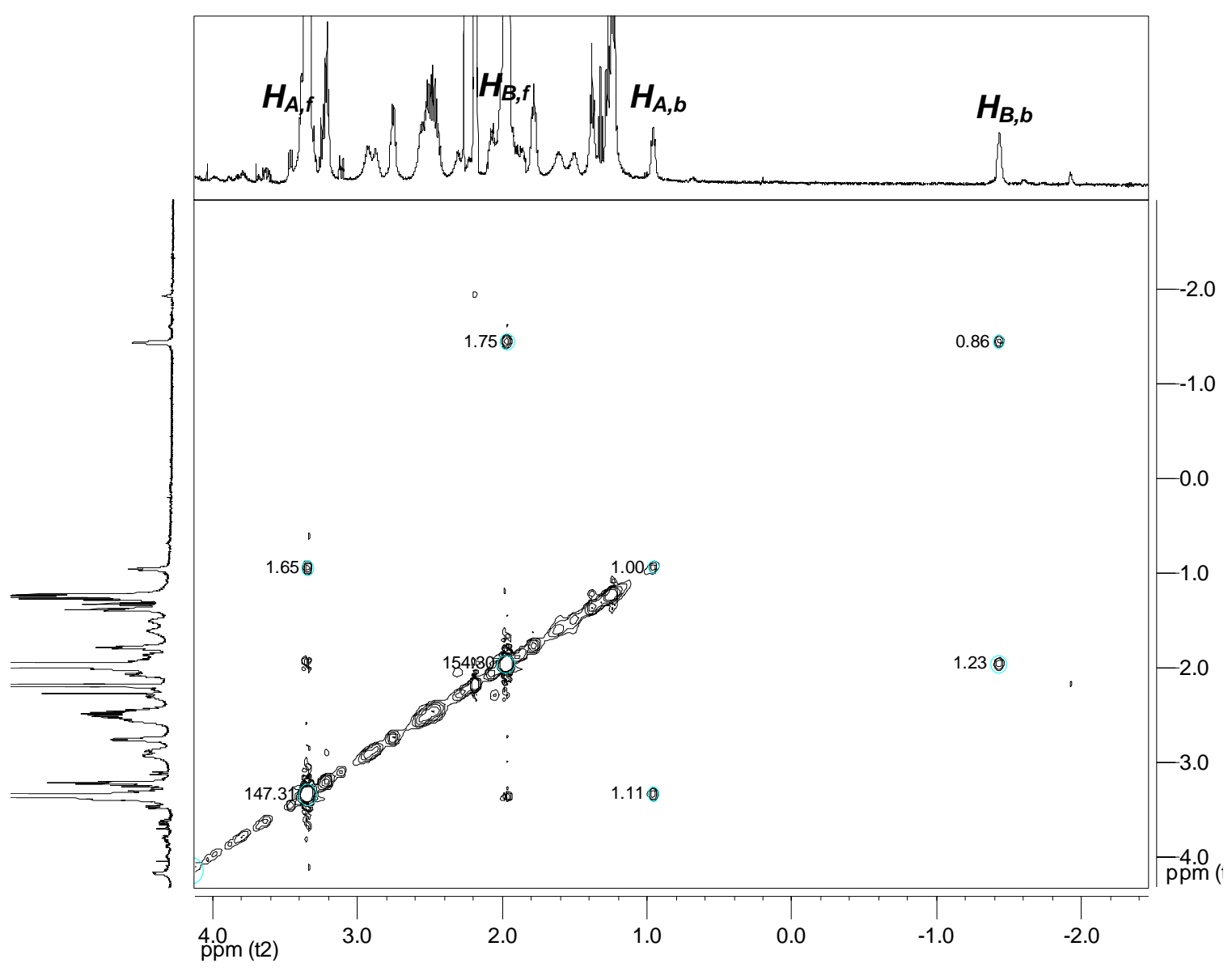

Figure S10. NOESY of $\mathbf{4 \cdot 6}$ in $\mathrm{D}_{2} \mathrm{O}$ taken with $400 \mathrm{~ms}$ mixing time. 


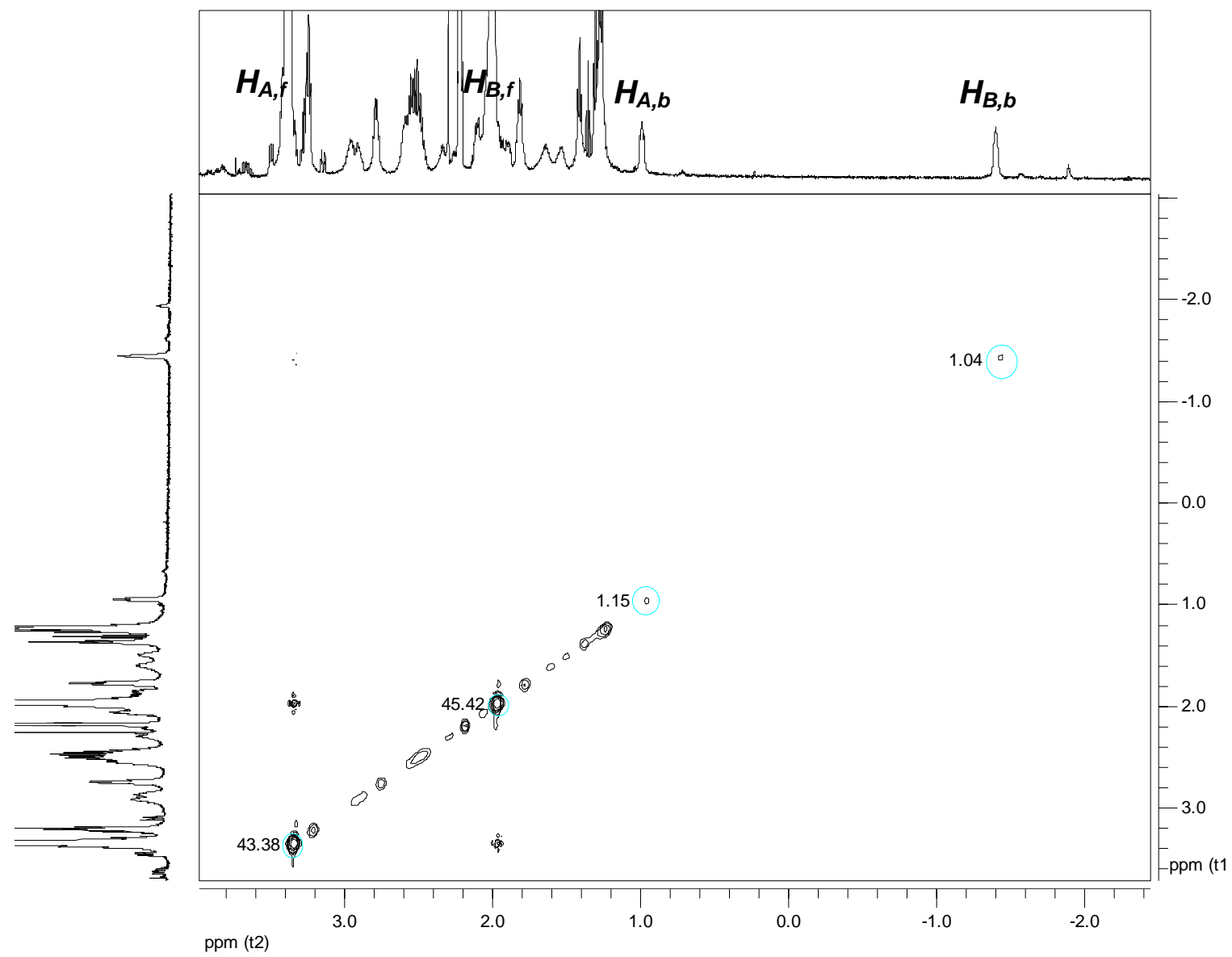

Figure S11. NOESY of $\mathbf{4 \cdot 6}$ in $\mathrm{D}_{2} \mathrm{O}$ taken with a 0 ms mixing time.

\footnotetext{
${ }^{1}$ Haino, T.; Rudkevich, D. M.; Shivanyuk, A.; Rissanen, K.; Rebek, J., Jr. Chem. Eur. J. 2000, 6, $3797-$ 3805.

${ }^{2}$ Perrin, C. L.; Dwyer, T. J. Chem. Rev. 1990, 90, 935-967.
} 